\title{
Chapter 9 \\ Swapping Development Rights \\ in Swampy Land: Strategic Instruments \\ to Prevent Floodplain Development \\ in Flanders
}

\author{
Ann Crabbé and Tom Coppens
}

Creating natural flooding areas to give way to water requires space. In practice, it is often difficult to deal with historically designated development rights, particularly in densely populated areas. Development rights are often seen as a part of land property rights of a land title and represent a certain financial value. Our contribution aims to describe how Flanders, the northern and Dutch speaking region of Belgium, struggles with (re)allocating development rights in flood-prone areas, highlighting that regular and innovative policy instruments significantly shape the behavioural responses of different actors in flood plains. In our article, we discern instruments for reallocation based on market approaches, government approaches and community approaches. From the Flemish context, we learn that (re)allocating development rights through government-based initiatives with financial compensations is still considered the most feasible approach, although the costs for the government may escalate. Even though Flanders is working with innovative instruments like trading development rights and exchange of development rights, they are expected not to fulfil the promise of becoming a true alternative for the central government-led initiatives. The main reason for that is that incentives to trade development rights or pool land are lacking as there is no real advantage for landowners nor municipal governments in participating in trade or pooling.

\footnotetext{
A. Crabbé $(\varangle)$

Faculty of Social Sciences, Centre of Research on Environmental and Social Change (CRESC), University of Antwerp, Antwerp, Belgium

e-mail: ann.crabbe@uantwerpen.be

T. Coppens

Faculty of Design Sciences, Research Group for Urban Development, University of Antwerp,

Antwerp, Belgium

e-mail: tom.coppens@uantwerpen.be
}

T. Hartmann et al. (eds.), Nature-Based Flood Risk Management on Private Land, https://doi.org/10.1007/978-3-030-23842-1_9 


\section{Introduction}

Climate change and increasing land coverage have an impact on flooding risks, even in areas that historically didn't have problems with water (Hellmann and de Moel 2014; Wheater and Evans 2009). In the evolution from technocratic "vertical" flooding policies to a socio-ecologic "horizontal" approach, most governments aim to restrict urbanisation of risk areas, in order to make "space for rivers" (Warner et al. 2012). The "space for rivers" thereby reflects a paradigm shift from a technological approach oriented toward containing and restraining water flows with the help of dikes and artificial basins versus a nature-based approach with loosely controlled natural flooding areas.

Creating natural flooding areas to give way to water requires space. In practice, it is often difficult to deal with historically designated development rights in these areas, in particular in densely populated areas. Development rights are often seen as a part of land property rights of a land title and represent a certain financial value (Nelson et al. 2013). Changing the development rights therefore results in a financial loss for the property owners. Property owners in flooding areas tend to oppose government initiatives to restrict new developments that often lead to a gap between water policies' goals and their effective implementation.

The most common instrument to (re)allocate development rights is through zoning or rezoning. However, this instrument is often not considered attractive, due to long procedures and expensive financial compensations. Next to zoning, alternative (innovative) instruments are being developed: (a) the system of tradable land development rights, which is a market-based instrument and (b) the system of exchange of development rights and land pooling (see box in Fig. 9.1).

Our contribution aims to describe how Flanders, the northern and Dutch-speaking region of Belgium, struggles with (re)allocating development rights in flood-prone areas, highlighting that regular and innovative policy instruments significantly shape the behavioural responses of different actors in flood plains. In the next section, we briefly describe flood risks in Flanders and some core characteristics of land use policy in Flanders. We introduce the idea of designating "signal areas" as a means to give policy priority to these areas where the planned land use conflicts with the potentially high flood risk damage. We discuss that changing development rights via (government-initiated) spatial implementation plans does not seem to be a very effective and time-efficient solution. This explains why the Flemish government decided to develop complementary and alternative instruments: trading development rights and mandatory land readjustment. We state that these innovative approaches are not (yet) a true alternative for a central government-led approach as the necessary incentives to trade development rights or pool land are structurally lacking. 


\section{Box 1: Three types of solutions for land management}

Governance problems such as water and land use management can typically be approached by three types of coordination mechanisms: markets, hierarchies and networks (Thompson, 1991). In the table below, we discern three types of solutions for the governance land management: a government-based, a market-based and a community-based solution. (a) The government-based solution is the most common, with a hierarchical government that intervenes with the idea that its intervention can influence or stimulate welfare for all. Classical land management instruments in a government-based approach are zoning, expropriation and (right of) pre-emption. (b) Market-based solutions and community-based solutions are much less practiced. In the market-based solution, land is considered an economic good with demand for and supply of land from societal/economic actors, that transact property rights. The government only intervenes in a facilitating role, not in an authoritative function. Transferable development rights are a typical land management instrument in a market-based approach (Nelson et al., 2013; Ward, 2013). (b) In a community-based approach land is considered part of the commons, for which collective action is needed. In that approach, citizens need negotiation and mutual coordination to settle land issues and develop institutions that govern common affairs (Ostrom, 1990). A typical land management instrument that fits a community-based approach is (voluntary or mandatory) land adjustment (van der Krabben \& Needham, 2008)

\begin{tabular}{|l|lll|}
\hline $\begin{array}{l}\text { Type of solution for land } \\
\text { management }\end{array}$ & $\begin{array}{l}\text { Government } \\
\text { based solution }\end{array}$ & $\begin{array}{l}\text { Market based } \\
\text { solution }\end{array}$ & $\begin{array}{l}\text { Community based } \\
\text { solution }\end{array}$ \\
\hline Allocation mechanism & Central planning & "Invisible hand" & $\begin{array}{l}\text { Negotiation and mutual } \\
\text { coordination }\end{array}$ \\
& $\begin{array}{l}\text { Interventionist welfare } \\
\text { economics theories }\end{array}$ & $\begin{array}{l}\text { Transaction costs and } \\
\text { property right theories }\end{array}$ & $\begin{array}{l}\text { Commons, theories on collective } \\
\text { action }\end{array}$ \\
$\begin{array}{l}\text { Typical land management } \\
\text { instruments }\end{array}$ & $\begin{array}{l}\text { Zoning, expropriation, } \\
\text { right of pre-emption }\end{array}$ & $\begin{array}{l}\text { Transferable } \\
\text { development rights }\end{array}$ & $\begin{array}{l}\text { Voluntary land re-adjustments } \\
\text { Mandatory land re-adjustment }\end{array}$ \\
& & & \\
\hline
\end{tabular}

Fig. 9.1 Three types of solutions for land management 


\section{Flood Risks and Land Use Policy in Flanders}

\section{The Risk of Floods in Flanders}

Flood risk control poses an important challenge in Flanders, the low-lying part of Belgium. Geographically, it consists in a coastal basin plain in the north-west and a central plain, crossed by the river basin of the river Scheldt, the Yzer and the Meuse and their tributaries. With an average density of about 485 inhabitants per $\mathrm{km}^{2}$, the region has a high level of urbanization. Moreover, as the historical urbanisation mainly took place along the rivers, the river valleys tend to be the most populated areas, making them especially vulnerable to flood risks.

According to the OFDA/CRED international disaster database, the frequency of problematic floods has been increasing over the last years in Belgium (see www. emdat.be). River flooding occurs due to a combination of heavy rainfall and long periods of rain. Also sea storms can pose risks for cities along the estuaries of the Scheldt and Yzer. According to the Flanders climate report, $7.5 \%$ of the total surface is now exposed to an increased risk of flooding, affecting 220000 inhabitants. The same report estimates the average yearly costs of flooding damage at about EUR 50 million.

Current models predict an increase of flooding in the future. Although the exact impact of climate change on flood risk is still unclear (Brouwers et al. 2009), it is expected that changing land use patterns and soil sealing will result in an increase in peak loads of the river system. The total of sealed soil increased from 4 to $5 \%$ in 1976 to $12.9 \%$ in 2012, whereas the total share of urbanized land now approaches one third of the total surface (Departement Omgeving 2017). According to the Flemish administration, about 6 ha per day are converted to urban use. The high levels of urban sprawl in Flanders further present a particular challenge to flood control (De Decker 2011; Verbeek et al. 2014), with ribbon development and scattered, lowdensity development.

\section{Land Use Policy in Flanders}

In the federal state of Belgium, the competencies on spatial planning and environment are situated at the regional level. The current planning framework in Flanders is determined by the 1962 Belgian act on spatial planning, the 1997 structure plan, the 1999 decree and the 2009 Codex on spatial planning.

The Belgian 1962 act introduced a comprehensive set of hierarchical zoning plans on different scale levels. The plans on the regional level or the gewestplannen, which were developed and approved in the 1970s and the early 1980s, have been seminal for the Belgian planning system. They provided detailed zoning prescriptions for the whole territory that are still in place today (for an example, see Fig. 9.2). Because of an overestimation of the growth during the making of the gewestplannen, but also 


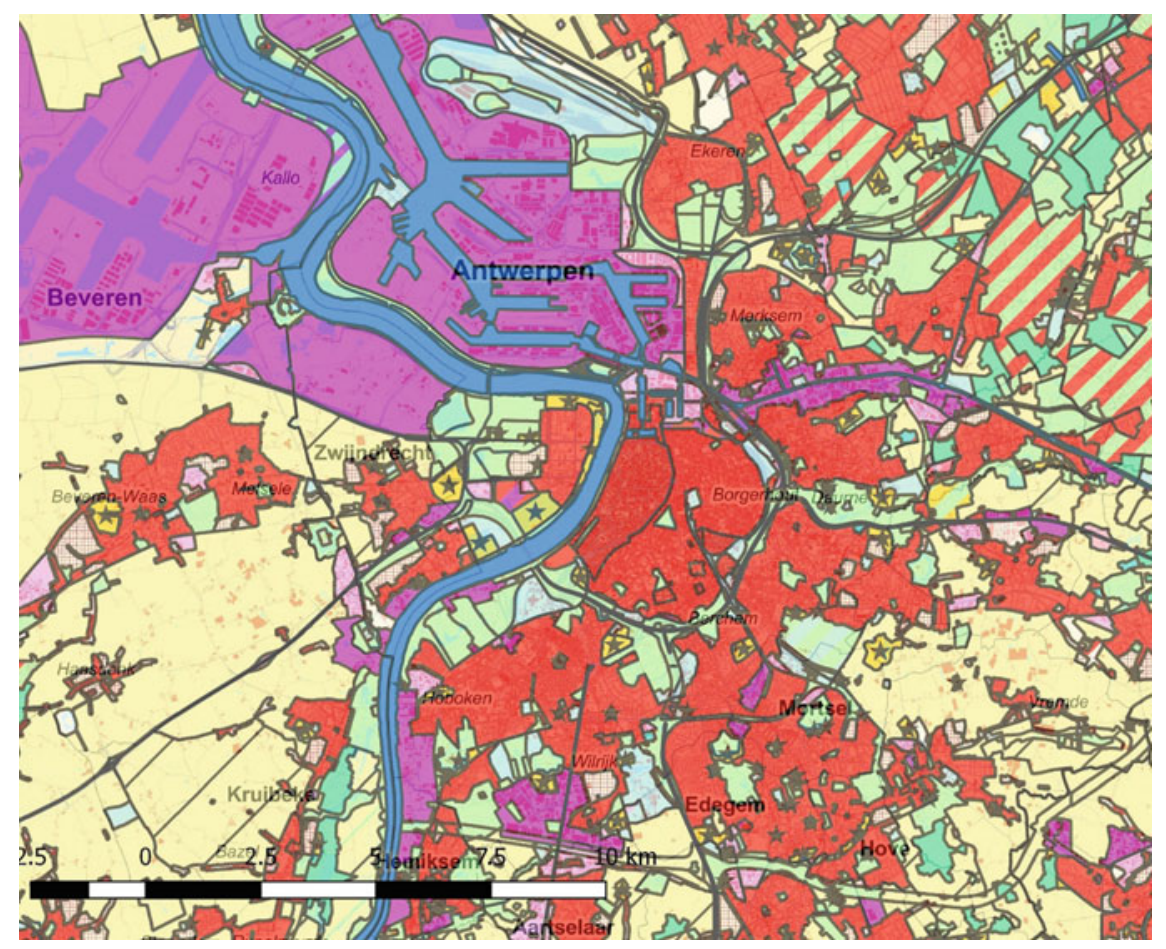

Fig. 9.2 The "gewestplan": land covering comprehensive zoning instrument. Source Extract of the regional zoning plan for Antwerp and surrounding municipalities; made in QGIS, based on the regional dataset of the 'gewestplan'

political lobbying from local governments resulting in an excess of supply in housing areas, many areas designated for development are still left unbuilt. The Flemish government estimates that about 41000 ha of designated land in the gewestplannen are still available for housing and mixed use developments, providing a large "juridical stock" of buildable land. A sizable share of this stock is located in water-prone areas.

The majority of this land belongs to private landowners who have development rights that are not restricted in time. Although one needs a building permit to build, in practice building permits in designated housing areas cannot just be refused without compensation. Moreover, the zoning of the gewestplannen has had a dramatic impact on land prices that fuelled land speculation. Whereas areas designated as "housing areas" have an average price of about EUR $180 / \mathrm{m}^{2}$ in Flanders (2014), the value of land zoned as agricultural land swings between EUR 4-5/ $\mathrm{m}^{2}$. This financial aspect makes changing the planned land use in Flanders particularly challenging. 


\section{Flood Risks Policy (Instruments) Flood Risk Policy in Flanders}

The Flemish policy on flood risk prevention is regulated by the 2003 Decree on Integrated Water Policy and the policy framework of 2005 and 2013, which assign implementation to the European Water Framework Directive of 2000. Severe floodings in 2010 and 2011 marked an increased policy attention to flood risk control but also a "window of opportunity" to implement another approach. Traditional technical flood protection policies oriented toward protection by dikes, retention basins and water pumping installations have been complemented by prevention and NBS with natural flooding areas and "natural" retention areas. This more ecological approach affects land use policy and in particular areas that are designated for housing and industry in flood risk areas.

The government has established a policy framework in 2013 to deal with new developments in flood-prone areas. In this context, the concept of "signal areas" (signaalgebieden) has been created: these are areas designated for industry or housing and with a potential impact on the water system. If after a further analysis it is concluded that flood damage risk increases when the area is developed according to the zoning designation, then the Flemish government concludes that this area needs a follow-up phase. In this follow-up phase, the Flemish government determines the development perspective for the area. Three development options are possible:

- Option A: the current designation is compatible with the water retention function, and building is possible with limited restrictions;

- Option B: the current designation has a moderate impact on flood risks, and building is possible with severe restrictions. Option B includes water-proof construction techniques and adaptive buildings;

- Option $\mathrm{C}$ : the current designation has a substantial impact on flood risks and building is prohibited.

Based on intensive discussions between the spatial planning department of the Flemish Government and other departments within the Coordination Commission on Integrated Water Policy, 3338 ha of land have now been labelled as signal area. About 2473 ha fall under development option C and need to be rezoned.

\section{Instruments for Land Use Management in Flood-Prone Areas}

The policy framework on the signal areas proposes a number of policy instruments to restrict and prohibit building in flood-prone areas. In the option A and option $\mathrm{B}$ areas, a number of instruments intend to prevent or mitigate the impact of new construction. 
- Building permits in areas with a flood risk need a water test. Water managers advise here regarding the following: (a) the potential impact of the building on the water system and (b) measures to mitigate or compensate these impacts.

- The instrument of information obligation includes that potential buyers or renters in risk-prone areas have to be informed explicitly regarding the risks of flooding when purchasing real estate.

- The governments also provides guidelines for adaptive building in water-prone areas; these are building construction techniques that reduce the impact on the water system and are able to cope with potential flooding.

For option $\mathrm{C}$ areas, zoning designations have to be changed, and more drastic instruments are needed. Zoning designations can be changed by spatial implementation plans or ruimtelijke uitvoeringsplannen. The Codex on spatial planning regulates the procedure, which foresees a public inquiry, and multiple rounds of advisements from both government administrations and advisory commissions. The procedure typically takes 2-3 years; implementation plans for more complex projects can even last 10 years. Implementation plans can be initiated by the municipal, provincial and regional level as long as they fit within their strategic structure plan. Implementation plans are also subject to environmental impact studies, which are regulated by separate environmental legalization.

Moreover, the 1962 Act and the later Codex protected landowners from value destruction as a result of rezoning in implementation plans with the instrument of plan compensation (planschade). Landowners that are faced with rezoning are compensated for $80 \%$ of the acquired value at current prices. Moreover, when option $\mathrm{C}$ is decided for a flood-prone area, it must be determined which level of the government (municipal, provincial or regional) has to take the initiative to start the procedure to make a spatial implementation plan or ruimtelijk uitvoeringsplan. Important to mention is that plan compensations have to be paid by the government level that takes the initiative. Local governments can rely on regional subsidies, but only for up to $60 \%$ of the costs for the plan compensations.

Because of the complexity of the instrument and the financial implications, governments are mostly reluctant to use implementation plans. An evaluation of the progress of redesignation in 83 signal areas found that for three quarters of the signal areas that need planning redesignation, procedures to develop spatial implementation plans had not been initiated yet. The Flemish government initiated 16 regional spatial implementation plans on signal areas; some provincial governments have also made spatial implementation plans on water-prone areas; but for municipal governments, it proved very difficult to redesignate water-prone areas via spatial implementation plans. The municipal governments indicate as a main reason a lack of clarity about the financial consequences and the fear for having to pay (large amounts of) financial compensations due to the development restrictions for landowners. While municipal governments are hesitant to initiate spatial implementation plan procedures, waterprone area are being developed, leading to high(er) risks of flood damage in these areas. 


\section{Flood Prone Open Space Areas as a Bypass}

In order to safeguard water-prone areas from further development, the Flemish government recently introduced the instrument of "flood prone open area spaces". With this instrument, the Flemish government has made it possible to change the current designation of signal areas to open space area. The "open space" designation leaves open which particular designation the area will receive (nature, agriculture, soft recreation...), but firmly confirms that the area cannot be developed. Some small developments will still be allowed, such as building little shelters as bus stops or building a functional road through the area, but high value development with residential homes and industry will not be allowed. Which areas will receive a flood-prone open space area designation will not be decided upon in a spatial implementation plan but in a circular note of the Flemish government.

Giving signal areas the planning designation of a flood-prone open space area via a circular note of the Flemish government has many advantages: (1) the responsibility to change planning designation is shifted from other governments towards the Flemish government, which releases more local governments from making unpopular decisions in complex spatial implementation plan procedures; (2) it adds speed to the process of taking away development rights in signal areas; (3) it creates more clarity and legal security for landowners who own land that is labelled as signal area; and (4) it enables a more centralized and uniform financial compensation policy for landowners who lose development rights.

The Flemish government decides which signal areas will receive a flood-prone open space area designation based on a suggestion by the Coordination Commission on Integrated Water Policy, in which not only the spatial department of the Flemish government but also provinces, municipalities and many other governmental agencies are represented. The decision on which planning redesignation will be assigned - by means of spatial implementation plans or by means of a circular note on water prone open space areas-will be made pragmatically. If procedures for spatial implementation plans have already been initiated, then signal areas will get a planning redesignation by means of a spatial implementation plan. If not, a circular note will be the alternative.

\section{The Biggest Challenge for Implementing the Flood Prone Open Space Area Policy}

The 2013 policy framework located the financial responsibility for compensating landowners in flood-prone areas at the government level that takes the initiative to make an implementation plan. In the new regulation, the minister for spatial planning has expressed that all compensations would be financed by the regional level. Moreover, the landowner will receive a financial compensation-not based on indexation of the purchase price but on the actual market value of the land. This means 
that financial compensation for losing development rights risks will become much more expensive for the Flemish government because purchase prices of land (even though indexated) are much lower than the actual market value of land. The spatial planning department therefore is urged to build more expertise in determining the actual market value of land by trying to systematically estimate the market value price of flood-prone signal area land. In these exercises, the spatial planning department starts off with the idea that market prices of signal areas are in practice lower because buyers anticipate that governments will not allow building on that land due to the signal area status.

The high cost of financially compensating the loss of development rights, together with the lack of experience and expertise on determining actual market prices of signal area land, are — at this moment_-important potential drawbacks in implementing the flood-prone open space area policy of the Flemish government.

\section{Are There Alternatives to Implementation Plans?}

Because of the bureaucratic complexity and the financial impact of implementation plans, the Flemish government has decided to develop complementary and alternative instruments.

\section{Trading Development Rights}

A new decree is underway with instruments to create a "market place" to trade development rights. The instrument of transferable development rights differentiates between sending areas and receiving areas; owners of flood-prone areas (sending areas) are compensated by owners buying development rights in the receiving areas.

In Flanders, municipal governments in particular are interested in the transferable development rights instrument. When a market place is created (when the transferable development rights-instrument is implemented), municipalities are relieved from the burden of financially compensating landowners because owners of areas receiving development rights financially compensate the owners of the sending areas.

The idea of transferring development rights on a "market place" is not really convincing for many. One has the illusion that the transferable development rights instrument would help to limit or take away development rights on land that should ideally not be built on, but it probably will not. Neither the owners of sending land nor the owners of receiving land seem to be very enthusiastic. (a) Owners of the sending area are not very keen on entering a market where the price of their land and/or development rights depend on the demand of others. They feel much more comfortable with the option that the government would fully financially compensate them for the loss of development rights and do not want to risk a volatile "bidding" among owners over receiving areas. (b) Owners of receiving areas do not have a 
proper incentive to pay for extra development rights on their land (e.g., building higher apartments), because the development rights on their (receiving) land already are rather permissive. Or, to put it differently, they are not pushed by "scarcity" that prevented them from paying for extra developments rights. They do not want to pay for something that is already allowed anyway.

Furthermore, scientific research concluded that the instrument of transferable development rights is not prohibiting open space to be built on (Ruimte Vlaanderen 2016; Van den Nieuwenhof 2016). Van den Nieuwenhof found that in order to withdraw the development rights of one piece of land, you have to attribute seven development rights in receiving areas in order to make the transfer of development rights financially interesting for the owners. Again, the main reason for that is that regulations on developments were and are quite permissive in Flanders. For example, many apartment buildings have been built in Flanders recently. This has caused an oversupply of apartments in the real property market. Developers are not interested in building higher apartment blocks, as they cannot find buyers. This makes attracting extra development rights not very interesting for them.

\section{Mandatory Land Readjustment, Including Swapping Designation Zones}

Land readjustment has been a common practice in many countries for decades (van der Krabben and Needham 2008). In Flanders, its purpose until now has been dominantly to pool fragmented properties and to redistribute property rights more efficiently. Typical applications are in agricultural and nature zones where parcels of land are swapped between the owners. The government delineates a district in which land reparcelling is possible, and, under the coordination of a government (land) agency, property owners are invited to collaborate and bring in their land as investment capital. In return, the agency commits to giving each owner a land site of at least equal value in the vicinity of the original site upon the completion of the land reparcelling project.

In case of mandatory land readjustment, the government puts land readjustment on the agenda to create a solution for problems with the planned land use and its associated development rights. There are now a few emerging cases using the instrument to relocate development rights in flood-prone areas. In these cases, the government is eager to swap planning designations between parcels/landowners, in order to prevent flood-prone areas from being developed (further). In these cases, the landowners remain landowners (no expropriation) but are financially compensated for the loss of development rights on their land by swapping planning designations between parcels/landowners, for example, swapping building rights for rights to use the land as agricultural land.

The difference between the classic land reparcelling and the new mandatory land readjustment is that in classic land reparcelling it is about land with "soft" planning 
designations (such as agriculture and nature) while the mandatory land readjustment brings about an exchange of designations between land with soft designations and hard designations (e.g., residential area or industry zone) where development rights should be revoked.

The idea of mandatory land readjustment provokes the interest of municipal governments, mainly because of financial reasons. In contrast to paying financial compensations in case of a spatial implementation plan, municipalities are not obliged to compensate landowners that lose development rights. When designations are exchanged between parcels/landowners, owners are paid in real values.

In practice, however, the mandatory land readjustment is not expected to be a success. Many reasons can explain this.

(a) If municipal governments approach the Flemish land agency to swap development rights between owners, they often lack a vision for the entire district for land readjustment, while this is a fundamental condition for the Flemish land agency to start a project. If municipal governments have the idea to install a flood retention area on the flood-prone land, than they are obligated to actually implement a flood retention zone in the area. If they want a land readjustment, then the land reparcelling should actually be done within the project. In summary, in contrast to the "flood-prone open space area"-instrument, where the exact designation of the open space can be determined later, mandatory land readjustments with designation swapping implies immediate choices on the final designation of the land and immediate implementation measures. These obligations are expected to keep municipal governments from actually starting up these types of projects.

(b) Landowners are often reluctant to swap designations as they prefer to be financially compensated by the government for losing development rights instead of being compensated in real value. The land readjustment then leads to a spatial implementation plan in which development rights are taken away from parcels, but landowners will ask for extra favours, for example, extra development rights on other parcels or permission to build pale dwellings on their land.

(c) One cannot easily find parcels to match. In Flanders with its strong urbanization, where can one find yet another zone where one could redesignate land with a soft planning designation to land with a hard planning designation?

\section{In Summary: Market- and Commons-Led Initiatives Are not yet a True Alternative for a Central Government-Led Approach}

From the Flemish context we learn that (re)allocating development rights through central government-led initiatives with financial compensations is still considered the best approach, because it is the fastest way to avoid (further) development of flood-prone areas and because it is an appealing scenario for municipal governments 
and landowners. A big drawback to these central government-led initiatives is that committing to these financial compensation carries the risk of becoming too great a financial burden, in particular when the government financially compensates at the rate of the actual market value of the land.

Even though Flanders is working with innovative instruments like trading development rights and exchange of development rights, they are not expected to fulfil the promise of becoming a true alternative for the central government-led initiatives. The main reason for that is that incentives to trade development rights or pool land are lacking since landowners do not see the advantage of participating in trade or pooling.

Acknowledgements Open access of this chapter is funded by COST Action No. CA16209 Natural flood retention on private land, LAND4FLOOD (www.land4flood.eu), supported by COST (European Cooperation in Science and Technology).

\section{References}

Brouwers J, Peeters B, Willems P, Deckers P, De Maeyer PH, Vanneuville W (2009) Klimaatverandering en waterhuishouding. In: Van Steertegem M (ed) Milieuverkenning 2030: milieurapport Vlaanderen, Vlaamse Milieumaatschappij, pp 283-304

De Decker P (2011) Understanding housing sprawl: the case of Flanders, Belgium. Environ Plann A 43(7):1634-1654. https://doi.org/10.1068/a43242

Departement Omgeving (2017) Ruimterapport Vlaanderen, Open Ruimte. Brussel

Hellmann FA, de Moel H (2014) Future land use patterns in European river basins: scenario trends in urbanization, agriculture and land use. In: Risk-informed management of European river basins. Springer, Berlin, Heidelberg, pp 209-222. https://doi.org/10.1007/978-3-642-38598-8_7

Nelson AC, Pruetz R, Woodruff D (2013) The TDR handbook: designing and implementing transfer of development rights programs. Island Press, Washington, D.C.

Ostrom E (1990) Governing the commons: the evolution of institutions for collective action, 1st edn. Cambridge University Press, Cambridge/New York

Ruimte Vlaanderen (2016) Adviesnota Verhandelbare Ontwikkelingsrechten. Available via DIALOG. https://www.ruimtevlaanderen.be/Portals/108/Adviesnota_verhandelbare_ ontwikkelingsrechten_2016.pdf

Thompson G (1991) Markets, hierarchies and networks: the coordination of social life. SAGE Publishing, London

Van den Nieuwenhof L (2016) Toepasbaarheid van verhandelbare ontwikkelingsrechten in Vlaanderen: is het concept verhandelbare ontwikkelingsrechten toepasbaar in gemeentelijk beleid in Vlaanderen? Master's thesis, University of Antwerp

van der Krabben E, Needham B (2008) Land readjustment for value capturing. A new planning tool for urban redevelopment. Town Plann Rev 79(6):651-672

Verbeek T, Boussauw K, Pisman A (2014) Presence and trends of linear sprawl: explaining ribbon development in the north of Belgium. Landscape Urban Plann 128:48-59. https://doi.org/10. 1016/j.landurbplan.2014.04.022

Ward P (2013) On the use of tradable development rights for reducing flood risk. Land Use Policy 31:576-583. https://doi.org/10.1016/j.landusepol.2012.09.004

Warner JF, van Buuren A, Edelenbos J (2012) Making space for the river. IWA Publishing, London

Wheater H, Evans E (2009) Land use, water management and future flood risk. Land Use Policy 26:251-264. https://doi.org/10.1016/j.landusepol.2009.08.019 
Ann Crabbé is guest professor and senior researcher at the Research Centre for Environmental and Social Change at the Sociology department of the University of Antwerp (Belgium). Her research interests include institutional stability and dynamics in the governance of flood risks. After her Ph.D. on institutionalizing the river basin approach in Flanders, she was involved in several regional and European projects on water quality policies and flood risk governance.

Tom Coppens is Associate Professor of Urban Planning at the University of Antwerp and coordinator of the master programme in urban planning and design. He is an expert in planning instruments and spatial governance processes in Flanders and opinion maker on urban planning policy. His research focus lies on tradable development rights and planning instruments for the reallocation of building rights.

Open Access This chapter is licensed under the terms of the Creative Commons Attribution 4.0 International License (http://creativecommons.org/licenses/by/4.0/), which permits use, sharing, adaptation, distribution and reproduction in any medium or format, as long as you give appropriate credit to the original author(s) and the source, provide a link to the Creative Commons license and indicate if changes were made.

The images or other third party material in this chapter are included in the chapter's Creative Commons license, unless indicated otherwise in a credit line to the material. If material is not included in the chapter's Creative Commons license and your intended use is not permitted by statutory regulation or exceeds the permitted use, you will need to obtain permission directly from the copyright holder.

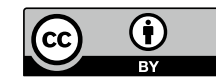

